\title{
Epidemiological status of bovine tuberculosis in the state of Minas Gerais, Brazil, 2013
}

\section{Situação epidemiológica da tuberculose bovina no estado de Minas Gerais, 2013}

\author{
Jonata de Melo Barbieri' ${ }^{1}$; Luciana Faria de Oliveira ${ }^{2}$; Elaine Maria Seles \\ Dorneles ${ }^{3}$; Ana Lourdes Arrais de Alencar Mota ${ }^{4}$; Vitor Salvador Picão Gonçaves ${ }^{5}$; \\ Patrícia Prata Maluf ${ }^{2}$; José Soares Ferreira Neto ${ }^{6}$; Fernando Ferreira ${ }^{5}$; Ricardo \\ Augusto Dias ${ }^{5}$; Evelise Oliveira Telles ${ }^{5}$; Jose Henrique Hildebrand Grisi-Filho ${ }^{5}$; \\ Marcos Bryan Heinemann ${ }^{5}$; Marcos Amaku ${ }^{7}$; Andrey Pereira Lage ${ }^{8, *}$
}

\begin{abstract}
A cross sectional study was performed to assess the epidemiological status of bovine tuberculosis in the state of Minas Gerais, Brazil, in 2013. The state was divided into seven regions, and a preset number of herds was randomly sampled in each region. From each farm, female cattle aged 24 months or older were randomly sampled and subjected to the comparative cervical tuberculin test (CCTT). Animals with inconclusive test results were re-tested with the same diagnostic procedure after a minimum interval of 60 days. A total of 31832 animals were tested from 2182 farms. An epidemiological questionnaire was administered in the farms to identify risk factors associated with bovine tuberculosis. Prevalence in the state was estimated at 4.25\% (95\% CI: $3.36 \%-5.15 \%)$ for herds and at $0.56 \%$ (95\% CI: $0.46 \%$ $-0.66 \%$ ) for animals. Data on herd prevalence for bovine tuberculosis for each stratum showed the highest prevalences at region Sul e Sudoeste (stratum 5) and region Central (stratum 3) which were significantly different from the lowest prevalences found at regions Noroeste, Norte e Nordeste (stratum 1) and region Leste (stratum 2). The highest animal prevalences observed for the region Sul e Sudoeste (stratum 5), region Zona da Mata (stratum 4) and region Central (stratum 3) were significantly different from the lowest ones at region Triângulo Mineiro (stratum 7), region Noroeste, Norte, e Nordeste (stratum 1) and region Leste (stratum 2). The presence of bovine tuberculosis was associated with animal purchase from cattle traders $(\mathrm{OR}=2.59$ [95\% CI: $1.28-5.20])$, higher yield intensive dairy
\end{abstract}

\footnotetext{
${ }^{1}$ Discente do Curso de Doutorado do Programa de Pós-Graduação em Ciência Animal, Laboratório de Bacteriologia Aplicada, Departamento de Medicina Veterinária Preventiva, Escola de Veterinária, Universidade Federal de Minas Gerais, UFMG, Belo Horizonte, MG, Brasil. E-mail: jonata_melobarbieri@hotmail.com

${ }^{2}$ Coordenadoras Estaduais, Programa Nacional de Controle e Erradicação de Brucelose e Tuberculose Animal, Instituto Mineiro de Agropecuária, IMA, Belo Horizonte, MG, Pesquisadora, Escola de Veterinária, UFMG, Belo Horizonte, MG, Brasil. E-mail: luciana.oliveira@ima.mg.gov.br; patrícia.maluf@ima.mg.gov.br

${ }^{3}$ Prof ${ }^{a}$, Departamento de Medicina Veterinária, Universidade Federal de Lavras, UFLA, Lavras, MG, Pesquisadora, Escola de Veterinária, UFMG, Belo Horizonte, MG, Brasil E-mail: elaine.dorneles@dmv.ufla.br

${ }^{4}$ Médica Veterinária, Pesquisadora, Faculdade de Agronomia e Medicina Veterinária, Universidade de Brasília, UnB, Brasília, DF, Brasil. E-mail: analourdes@unb.br

${ }_{5}^{5}$ Prof., Faculdade de Agronomia e Medicina Veterinária, Universidade de Brasília, UNB, Brasília, DF, Brasil. E-mail: vitorspg@ unb.br

${ }^{6}$ Profs., Faculdade de Medicina Veterinária e Zootecnia, Universidade de São Paulo, USP, São Paulo, SP, Brasil. E-mail: jsoares@, vps.fmvz.usp.br; fernando@vps.fmvz.usp.br; dias@vps.fmvz.usp.br; bufalo@usp.br; grisi@vps.fmvz.usp.br; marcosbryan@ usp.br

7 Prof., Faculdade de Medicina, Universidade de São Paulo, FMUSP/USP, São Paulo, Brasil. E-mail: amaku@vps.fmvz.usp.br

8 Prof., Departamento de Medicina Veterinária Preventiva, Escola de Veterinária, UFMG, Belo Horizonte, MG, Brasil. E-mail: alage@vet.ufmg.br

* Author for correspondence
} 
$(\mathrm{OR}=7.55$ [95\% CI: $1.89 \%-30.09 \%])$ and non-intensive dairy production $(\mathrm{OR}=3.58$ [95\% CI: $1.06 \%$ $-12.04 \%]$ ), as well as with herds with 30 or more cows (OR=1.97 [95\% CI: $1.02-3.80]$ ). Non-specific reactors to the CCTT were found in $95.07 \%$ (95\% CI: $94.05 \%-96.09 \%$ ) of the herds. Therefore, the state of Minas Gerais should implement surveillance systems for the detection and sanitation of infected herds, preferably incorporating risk-based surveillance elements, considering the results of the present study.

Key words: Brazil. Minas Gerais. Mycobacterium bovis. Prevalence. Risk factors.

\section{Resumo}

Foi realizado um estudo transversal para avaliar a situação epidemiológica da tuberculose bovina no estado de Minas Gerais em 2013. O Estado foi dividido em sete regiões e um número predefinido de fazendas foi amostrado aleatoriamente em cada região. Dentro de cada propriedade, fêmeas com idade igual ou superior a 24 meses foram escolhidas aleatoriamente e submetidas ao Teste Tuberculínico Cervical Comparativo (CCTT). Os animais com resultados inconclusivos foram retestados com o mesmo procedimento diagnóstico após um intervalo mínimo de 60 dias. Um total de 31832 animais foram testados provenientes de 2182 propriedades. Um questionário epidemiológico foi aplicado em cada fazenda para identificar fatores de risco associados à tuberculose bovina. A prevalência de focos no estado foi de 4,25\% (IC 95\%: 3,36 - 5,15) e 0,56\% (IC 95\%: 0,46 - 0,66) de animais. Em relação a prevalência de rebanho com tuberculose bovina para cada estrato, as maiores prevalências foram observadas nas regiões Sul e Sudoeste (estrato 5) e Central (estrato 3), que foram significativamente diferentes das menores prevalências encontradas nas regiões Noroeste, Norte e Nordeste (estrato 1) e Leste (estrato 2). As maiores prevalências de animais observadas nas regiões Sul e Sudoeste (estrato 5), Zona da Mata (estrato 4) e Central (estrato 3) foram significativamente diferentes das menores encontradas nas regiões do Triângulo Mineiro (estrato 7), Noroeste, Norte, e Nordeste (estrato 1) e Leste (estrato 2). A presença de tuberculose bovina foi associada com a compra de animais de comerciantes de gado $(\mathrm{OR}=2,59$ [IC 95\%: 1,28-5,20]), propriedades leiteiras tecnificadas ( $\mathrm{OR}=7,55$ [IC 95\%: 1,89\% $30,09 \%]$ ) e propriedades leiteiras não-tecnificadas (OR [IC 95\%: 1,06\% - 12,04\%] =3,58), bem como com rebanhos com 30 ou mais fêmeas (OR $=1,97$ [95\% IC: 1,02-3,80]). Reações inespecíficas ao CCTT foram observadas em cerca de 95,07\% (IC 95\%: 94,05 - 96,09\%) dos rebanhos. Portanto, o estado de Minas Gerais deve implementar sistemas de vigilância para a detecção e saneamento dos rebanhos infectados, de preferência incorporando elementos de vigilância com base no risco, considerando os resultados do presente estudo.

Palavras-chave: Brasil. Fatores de risco. Minas Gerais. Mycobacterium bovis. Prevalência.

\section{Introduction}

Bovine tuberculosis is a chronic infectious disease caused by Mycobacterium bovis and an important zoonosis entailing public health risks and economic losses to farmers, such as decrease of milk production, decrease in weight gain, loss of commercial value, and culling of skin test reactor cattle (BRASIL, 2006; SKUCE et al., 2012). Tuberculosis causes typical granulomatous lesions both in humans and animals with varying degrees of necrosis, encapsulation, and calcification in the lung region due to its transmission by inhalation of contaminated aerosols, especially among animals (bovine-bovine transmission) (POLLOCK et al., 2006). Infection can also occur via the gastrointestinal tract, thereby affecting other organs such as the intestine and mesenteric lymph nodes (O'REILLY; DABORN, 1995). These extrapulmonary manifestations are more common in calves and in animal-man transmission, due to raw milk and dairy products consumption habits (MICHEL et al., 2010).

Owing to its zoonotic character and the economic losses on the meat and milk supply chains, bovine tuberculosis is the object of control and eradication programs in several countries. Brazil initiated 
effective control of the disease in 2001, with the publication of the Programa Nacional de Controle e Erradicação de Brucelose e Tuberculose Animal - PNCEBT (National Program on the Control and Eradication of Animal Brucellosis and Tuberculosis ) (BRASIL, 2006), by the Ministério da Agricultura, Pecuária e Abastecimento - MAPA (Ministry of Agriculture, Livestock and Food Supply). The aim of the program is to reduce the prevalence and incidence of these zoonoses, and thus contribute to the livestock market evolution both at national and international levels. The main rules imposed by PNCEBT cover the certification of free and monitored herds and the requirement of negative testing for the movement of animals. Due to the lack of incentives to producers, voluntary certification of herds is low; in Minas Gerais only 43 herds had reached the free status in 2013 (OLIVEIRA, 2016). These activities are developed by accredited veterinarians who were approved on short courses of standardization of testing procedures and control of bovine tuberculosis recognized by MAPA.

Studies on the epidemiological status of bovine tuberculosis performed in 13 Federative Units of Brazil, which hold $75 \%$ of cattle in the country, showed herd prevalences ranging from $0.36 \%$ in Distrito Federal to $9.0 \%$ in São Paulo (BAHIENSE et al., 2016; BELCHIOR et al., 2016; DIAS et al., 2016; GALVIS et al., 2016; GUEDES et al., 2016; LIMA et al., 2016; NÉSPOLI et al., 2016; QUEIROZ et al., 2016; RIBEIRO et al., 2016; ROCHA et al., 2016; SILVA et al., 2016; VELOSO et al., 2016; VENDRAME et al., 2016). These studies also identified the following risk factors: dairy production usually associated with larger intensive herds, with higher yields, use of common pastures by different herds, and animal purchase.

Minas Gerais holds a prominent position in the country's livestock industry, accounting for a third of the country's milk production (IBGE, 2006). The State holds the largest dairy herd and the secondlargest cattle herd in the country (ANUALPEC,
2014). In 1999, a survey for bovine tuberculosis was performed in Minas Gerais. Although it did not cover the whole state territory, leaving the northern regions out of the target population, 1586 herds and 22990 cattle were tested, within an area that corresponded to approximately $70 \%$ of the cattle, $75 \%$ of the herds, and $86 \%$ of the state's milk production, in the year of the study. The apparent prevalence was estimated at 5.04\% (95\% CI: 4.96\% $-5.13 \%$ ) for herds and at $0.81 \%$ (95\% CI: $0.37 \%-$ $1.25 \%$ ) for animals (BELCHIOR et al., 2016).

Despite the relatively low prevalence of bovine tuberculosis observed in the Brazilian states, the situation between them is heterogeneous. The frequent report of animals with clinical signs of the disease in the country is a matter of concern because of its impact on milk and meat production as well as its zoonotic potential (OIE, 2015).

The main purpose of the present study was to estimate the prevalence of bovine tuberculosis in Minas Gerais with a view to identify possible changes since 1999 and to make up for the lack of epidemiological information on the northern regions of the state, for which there was no structured survey data available to date.

\section{Material and Methods}

\section{Location}

An epidemiological cross-sectional study was carried out in the state of Minas Gerais located in Brazil's southeastern region between the parallels of latitude, south $14^{\circ} 13^{\prime} 58^{\prime \prime}$ and $22^{\circ} 54^{\prime} 00^{\prime \prime}$, and

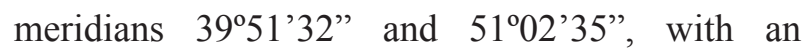
extension of 58652123.5 hectares, and a total of 317859 cattle farms in 2013 (IMA, 2013). In 2013, the state of Minas Gerais had 24201256 cattle (IBGE, 2013), accounting for $26.6 \%$ of the national production and $77 \%$ of the Southeast region milk production. 


\section{Sample design}

The state of Minas Gerais was divided into seven strata (Figure 1), representing different regions characterized by the frequency of distinct parameters such as production systems, production purpose, animal handling, and average herd size (ALVES,
2009; OLIVEIRA, 2016). This stratification was similar to that used by Gonçalves et al. (2009) and Oliveira et al. (2016) in studies on the prevalence and risk factors of brucellosis in the state of Minas Gerais, and it was validated by Alves (2009) and Oliveira (2016).

Figure 1. Map of Minas Gerais showing the seven strata sampled in this study.

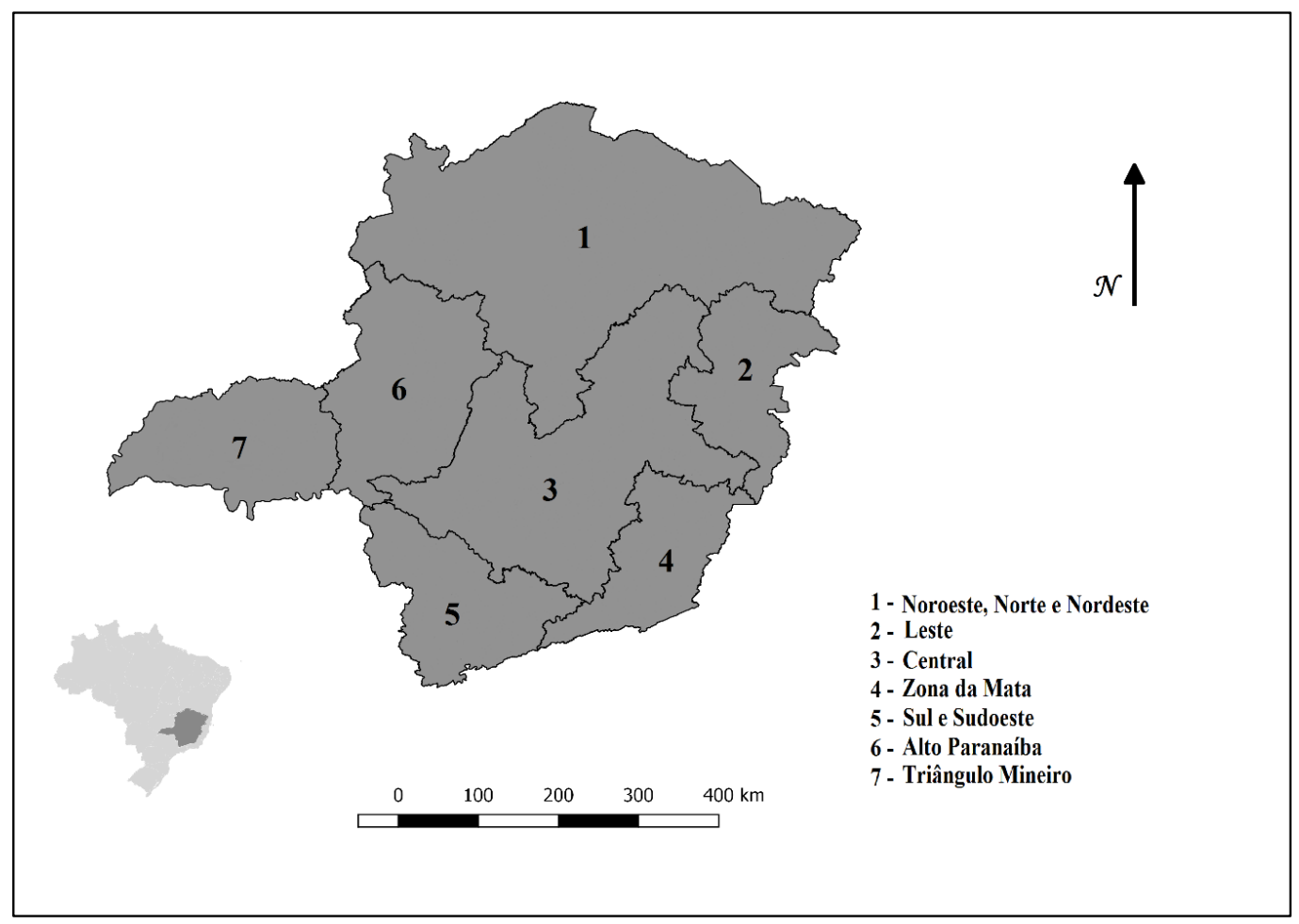

Sampling was performed by randomly selecting a preset number of herds in each stratum (primary sampling units). Then, the sanitary condition of the herds were assessed by randomly selecting a predetermined number of cows aged 24 months or more (secondary units). This two-level sampling was performed using the register of properties of Instituto Mineiro de Agropecuária - IMA (State Animal Health Authorirty) and covered all 853 municipalities of Minas Gerais. Most herds (99.95\%) were sampled in 2013; and a single farm $(0.05 \%)$ was sampled in 2014.

The herds in each stratum were randomly selected and the study focused on herds with reproductive activity in farms where the animals were subjected to the same breeding conditions. The selected farms had been randomly sampled during the epidemiological study of bovine brucellosis in the state of Minas Gerais in 2011 (OLIVEIRA et al., 2016; OLIVEIRA, 2016). For each stratum, the sample size was determined using the equation for simple random sampling (THRUSFIELD, 1995; NOORDHUIZEN et al., 1997). When it was not possible to collect data on the same farm of the epidemiological study on brucellosis, either a neighboring property or a new randomly selected farm was used.

In order to calculate the sample size, the following 
parameters were used: $Z \alpha=$ value of the normal distribution for the specified degree of confidence (95\%), $\mathrm{P}=$ expected prevalence $7.1 \%$ (upper limit of the confidence interval of the estimated herd prevalence (GONÇALVES et al., 2009), and $d=$ precision, fixed at $3 \%$.

The resulting number of herds was 2185 , with approximately 300 herds sampled in each stratum. From these, 2130 were the same herds sampled in the 2011 epidemiological study on brucellosis in Minas Gerais (OLIVEIRA et al., 2016); 52 herds were different and a loss of information occurred for three herds for which the data were not processed in the import process. Thus, in the present study, 2182 herds were assessed.

The secondary units were cows aged 24 months or older in each of the sampled herds. In herds with up to 99 cows in this age group, 20 cows were randomly sampled. If the total number of cows was lower than 20, all cows were sampled. In both cases, the presence of one positive animal in comparative cervical tuberculin test (CCTT) classified the herd as a focus of bovine tuberculosis. In farms with more than 99 cows in the target age group, 40 cows were randomly sampled and a herd was classified as a focus of bovine tuberculosis if at least two animals were positive in CCTT. This sampling scheme resulted in a herd sensitivity and specificity greater than 90\% (JORDAN; McEWEN, 1998; SERGEANT et al., 2009). Cows in the peripartum period were excluded to avoid false-negative results. The same thresholds were used to classify herds with non-specific reactors in CCTT. Finally, a total of 31832 animals were subjected to CCTT.

\section{Diagnostic methods}

Bovine tuberculosis diagnosis was carried out using comparative cervical tuberculin test (CCTT), according to PNCEBT (BRASIL, 2006). Animals with inconclusive results were re-tested after a minimum interval of 60 days. Inconclusive results after the second test were considered positive (BRASIL, 2006).

\section{Data source}

Information was collected from the participating herds through an epidemiological survey questionnaire administered by state veterinarians of the IMA. This questionnaire included the characterization of breeding processes and sanitary conditions, as well as other important factors reported in the literature regarding the disease, in order to assess risk factors associated with the occurrence of bovine tuberculosis, which included the following: type of farm, the presence of wild animals, herd size, animal purchase and sale, renting or sharing of pastures between farms, type of breeding, artificial insemination, and vaccination.

Statistical analysis: Calculation of the apparent prevalence and risk factors

In order to calculate the apparent prevalence within each strata, the ratio between herds with cattle positive for bovine tuberculosis in the sample and the total number of herds sampled in the stratum was used, with confidence intervals calculated by the exact binomial distribution (ZAR, 2010). The weighting of herds (sample weight) within each stratum was carried out to calculate the apparent prevalence. The inverse of the sample selection probability was used to obtain the sample weights, reflecting, therefore, the number of individuals representing each herd sampled (BENNETT et al., 1991; DOHOO et al., 2003). Thus, the weight (P1) corresponding to each herd within the stratum, was given by the following equation:

$$
P_{1}=\frac{N^{o} \text { of herds in the stratum }}{N^{o} \text { of herds sampled in the stratum }}
$$

To calculate the prevalence of bovine tuberculosis among animals, the weighting was performed in two stages. The first ratio determined the weight of each animal within the sampled herd and the second ratio gave the weight of each animal within the stratum (GONÇALVES et al., 2009). Thus, the weight (P2) 
corresponding to each animal in the stratum was calculated as follows:

$$
\begin{gathered}
P_{2}=\frac{\text { cows } \geq 24 \text { months in the herd }}{\text { cows } \geq 24 \text { months sampled in the herd }}+ \\
\frac{\text { cows } \geq 24 \text { months in the stratum }}{\text { cows } \geq 24 \text { months sampled in the stratum }}
\end{gathered}
$$

Table 1 shows herd and cattle population data of the state of Minas Gerais (IMA VA-1/2013) (IMA, 2013), which were used for the calculation of P1 and P2 for each stratum in 2013. In addition, the prevalence of herds showing animals with nonspecific reactions, i.e., animals exhibiting a higher reaction to avian tuberculin compared to bovine tuberculin on the CCTT (BRASIL, 2006), was also

\begin{tabular}{|c|c|c|c|c|c|}
\hline & Stratum & $\begin{array}{l}\text { Total number } \\
\text { of herds with } \\
\text { productive } \\
\text { activity }\end{array}$ & $\begin{array}{c}\text { Herds } \\
\text { sampled }\end{array}$ & $\begin{array}{c}\text { Total number of } \\
\text { females aged } \geq 24 \\
\text { months }\end{array}$ & $\begin{array}{c}\text { Number of } \\
\text { females aged } \\
\geq 24 \text { months } \\
\text { sampled }\end{array}$ \\
\hline 1 & Noroeste, Norte e Nordeste & 83439 & 346 & 84271 & 4588 \\
\hline 2 & Leste & 26342 & 301 & 83955 & 5418 \\
\hline 3 & Central & 72462 & 377 & 85095 & 5028 \\
\hline 4 & Zona da Mata & 38044 & 312 & 85044 & 3899 \\
\hline 5 & Sul e Sudoeste & 51579 & 295 & 83850 & 3148 \\
\hline 6 & Alto Paranaíba & 24163 & 259 & 84944 & 4363 \\
\hline 7 & Triângulo Mineiro & 21830 & 292 & 84263 & 5388 \\
\hline Total & Minas Gerais & 317859 & 2182 & 591422 & 31832 \\
\hline
\end{tabular}
calculated taking into account the herd's weight.

Table 1. Cattle population and sampling data for the state of Minas Gerais, Brazil, 2013.

Risk factors were evaluated using the information obtained in the questionnaire as independent variables and the result of the diagnostic test for bovine tuberculosis as dependent variable. The variable "total number of cows in the herd" was reclassified based on the median of the variable into herds up to 29 cows and 30 or more cows. Some correlated and associated variables were grouped by creating a new variable "type of herd regarding intensity of production" with the following categories: intensive dairy production herds, nonintensive dairy production herds and beef herds. Herds that used milk cooling systems, mechanical milking, artificial insemination and milking carried out at least twice a day, were considered intensive dairy production herds. Dairy herds without those characteristics were classified as non-intensive dairy production herds. Beef producing herds were not reclassified.

Univariate analysis using the chi-square $\left(\chi^{2}\right)$ or Fisher's exact test was performed to determine the variables that were associated with the occurrence of bovine tuberculosis. The significance level adopted for the variable selection was $\mathrm{P} \leq 0.20$ (ZAR, 2010). These variables were used to build multiple logistic regression models with strength of association estimates by adjusted odds ratio (OR) and $95 \%$ confidence interval $(95 \% \mathrm{CI})$. The forward model was used for data entry, developed in design based-model, that is, taking into account the farm weights calculated within each stratum, assessing the population interaction between the factors associated with $\mathrm{P} \leq 0.05$ (HOSMER JUNIOR; LAMESHOW, 2000). All calculations related to 
logistic regression and prevalence were carried out using the statistical software Stata version $12 \AA$ (Statacorp, USA).

Spatial analysis of clustering of positive herds for bovine tuberculosis

The sampled herds were geographically referenced at the moment of the tuberculosis diagnosis test, and the positive and negative herds were plotted on a map of Minas Gerais (Figure 2 ). In order to assess the clustering of bovine tuberculosis-positive herds, the $\mathrm{K}$ function was applied, which provides a summary of the spatial dependence between events (randomness) as a function of the distance (ERSBOLL; ERSBOLL,
2009). Diggle and Chetwynd (1991) suggested the use of the function $\mathrm{D}$, defined by $\mathrm{D}(s)=\mathrm{K}_{11}(s)-$ $\mathrm{K}_{22}(s)$ or $\mathrm{D}(s)=\mathrm{K}_{11}(s) / \mathrm{K}_{22}(s)$, where $\mathrm{K}_{11}$ and $\mathrm{K}_{22}$ are the K-functions of event 1 (positive) and event 2 (negative), respectively, and D is the Euclidean distance between two points within the sample $s$. Thus, if D $(s)$ is a significantly positive value it indicates a grouping of the disease. The calculations of the K-function and the upper and lower envelope $\left(\mathrm{K}_{11}\right.$ and $\left.\mathrm{K}_{22}\right)$, were performed by the $\mathrm{R}$ software (R CORE TEAM, 2014) and its packages "splancs","maptools","rgdal" and "rgeos", in a total of 1000 simulations (BIVAND; RUNDEL, 2014; BIVAND; LEWIN-KOH, 2015; BIVAND et al., 2015; ROWLINGSON; DIGGLE, 2015).

Figure 2. Herds that were positive or negative for bovine tuberculosis in the epidemiological study performed in Minas Gerais, 2013.

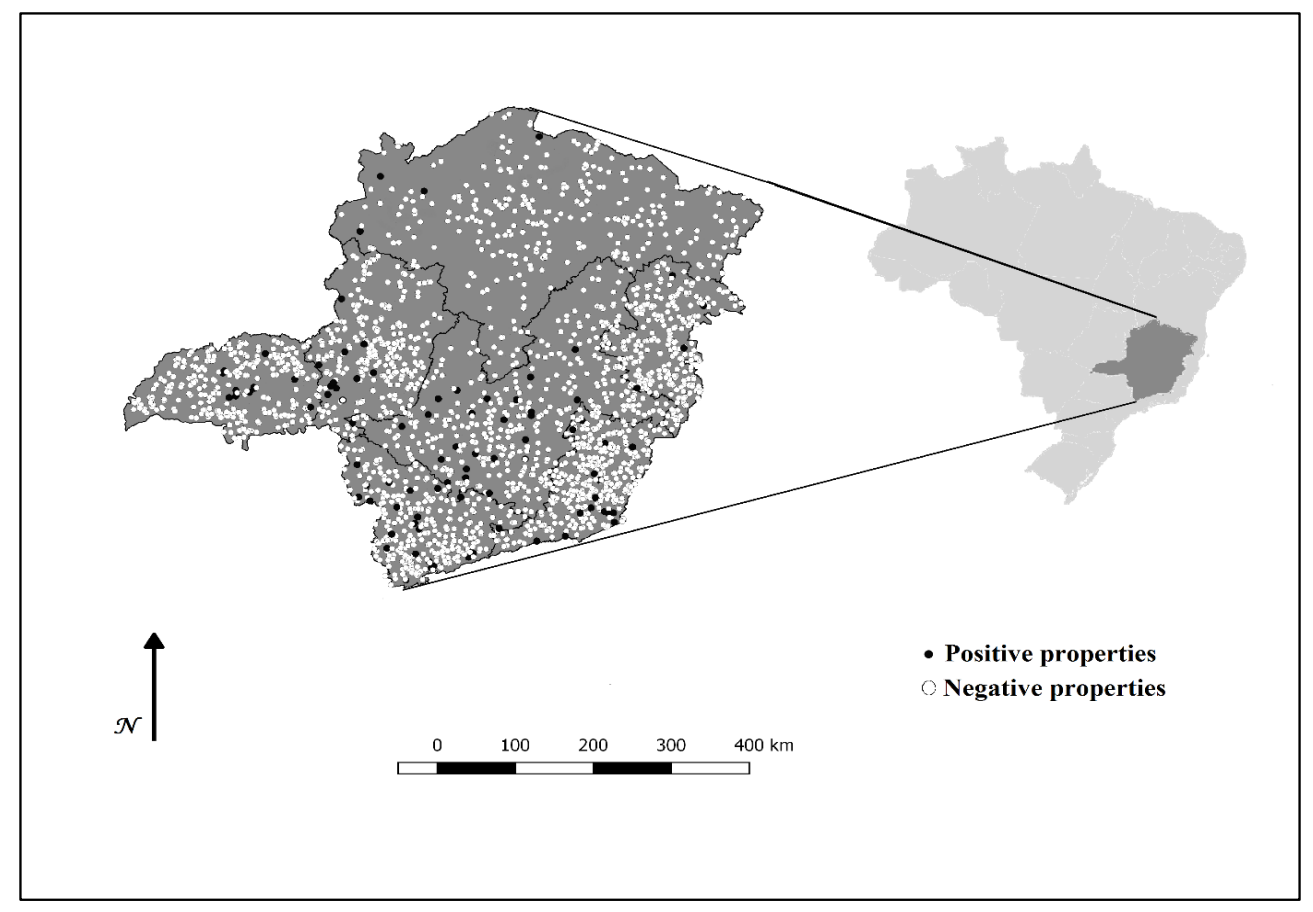

\section{Results}

Among the 2182 herds sampled, 93 showed bovine tuberculosis-positive animals $(4.25 \% ; 95 \%$ CI: $3.36 \%-5.15 \%$ ) (Figure 2). Data on herd prevalence for bovine tuberculosis for each stratum showed the highest prevalences at region Sul e
Sudoeste (stratum 5) and region Central (stratum 3) which were significantly different from the lowest prevalences found at region Noroeste, Norte e Nordeste (stratum 1) and region Leste (stratum 2) (Table 2 and Figure 3). Among the 31832 cattle tested in the state of Minas Gerais, 188 animals 
were positive for bovine tuberculosis $(0.56 \% ; 95 \%$ CI: $0.46 \%-0.66 \%)$. The highest animal prevalences observed for the region Sul e Sudoeste (stratum 5), region Zona da Mata (stratum 4) and region Central (stratum 3) were significantly different from the lowest ones at region Triângulo Mineiro (stratum 7), region Noroeste, Norte e Nordeste (stratum 1) and region Leste (stratum 2) (Table 3 and Figure 3). From the 2182 herds sampled, 2086 (95.07\%; 95\% CI: $94.05 \%$ - 96.09\%) showed non-specific reactors to CCTT and $51.09 \%$ (95\% CI: 50.25\% - 51.93\%) of the 31832 tested cattle were non-specific reactors (Figure 3).

Table 2. Apparent prevalence of herds with comparative cervical tuberculin test (CCTT)-positive cattle in the seven strata and in the state of Minas Gerais, 2013.

\begin{tabular}{|c|c|c|c|c|c|}
\hline \multirow{2}{*}{\multicolumn{2}{|c|}{ Stratum }} & \multicolumn{2}{|c|}{ Herds } & \multirow{2}{*}{$\begin{array}{c}\text { Prevalence } \\
(\%)\end{array}$} & \multirow{2}{*}{ CI $(95 \%)$} \\
\hline & & Sampled & Positive & & \\
\hline 1 & Noroeste, Norte e Nordeste & 346 & 4 & 1.15 & $0.02-2.28$ \\
\hline 2 & Leste & 301 & 5 & 1.65 & $0.20-3.09$ \\
\hline 3 & Central & 377 & 25 & 6.64 & $4.12-9.16$ \\
\hline 4 & Zona da Mata & 312 & 15 & 4.80 & $2.43-7.18$ \\
\hline 5 & Sul e Sudoeste & 295 & 20 & 6.77 & $3.90-9.65$ \\
\hline 6 & Alto Paranaíba & 259 & 11 & 4.24 & $1.78-6.70$ \\
\hline 7 & Triângulo Mineiro & 292 & 13 & 4.45 & $2.08-6.81$ \\
\hline Total & Minas Gerais & 2182 & 93 & 4.25 & $3.36-5.15$ \\
\hline
\end{tabular}

CI - Confidence interval.

Table 3. Apparent prevalence of comparative cervical tuberculin test (CCTT)-positive cattle in the seven strata and in the state of Minas Gerais, 2013.

\begin{tabular}{clcccc}
\hline \multirow{2}{*}{ Stratum } & \multicolumn{2}{c}{ Animals } & $\begin{array}{c}\text { Prevalence } \\
(\mathbf{\%})\end{array}$ & \multirow{2}{*}{ CI (95\%) } \\
\cline { 3 - 5 } & Sampled & Positive & 0.28 & $0.03-0.53$ \\
\hline 1 & Noroeste, Norte e Nordeste & 4588 & 6 & 0.28 & $0.12-0.43$ \\
2 & Leste & 5418 & 15 & 1.04 & $0.74-1.34$ \\
3 & Central & 5028 & 61 & 1.10 & $0.69-1.51$ \\
4 & Zona da Mata & 3899 & 33 & 1.36 & $0.86-1.86$ \\
5 & Sul e Sudoeste & 3148 & 37 & 0.47 & $0.18-0.77$ \\
6 & Alto Paranaíba & 4363 & 16 & 0.21 & $0.10-0.33$ \\
7 & Triângulo Mineiro & 5388 & 20 & $\mathbf{0 . 5 6}$ & $\mathbf{0 . 4 6 - 0 . 6 6}$ \\
\hline
\end{tabular}

CI - Confidence interval.

The variable "type of herd regarding intensity of production" was created from the variables milk cooling systems, use of mechanical milking and artificial insemination and the number of milkings per day. In the sample, $82.5 \%$ of the herds milk their cattle; $59.7 \%$ were classified as dairy herds and $22.8 \%$ as dual-purpose herds. One hundred and forty-seven herds, $6.74 \%$ of the sampled herds, were classified as intensive production dairy herds; those are composed of $10.3 \%$ of the previously classified as dairy herds and of $2.6 \%$ of the formerly dualpurpose herds.

The variables selected in the univariate analysis ( $P \leq 0.20$ in the chi-square or Fisher's exact test) for the multivariate logistic regression are shown in Table 4. In the logistic regression, only the following variables were kept in the model: "animal purchased 
from cattle trader", compared to herds without animals acquired from cattle traders; "intensive dairy production herds" and "non-intensive dairy production herds", both compared to the baseline lower risk category "beef herds"; and number of cows in the herd, using the median threshold of herds up to 29 cows and 30 or more cows (Table 5).
Clustering of bovine tuberculosis-positive herds was observed between approximately 50 and 600 $\mathrm{km}$, as the K-function increased above the upper simulation envelope between these distances (Figure 4).

Figure 3. Prevalence of bovine tuberculosis and non-specific reactions at animal and herd levels in Minas Gerais state, 2013. Strata were: 1 - Noroeste, Norte e Nordeste, 2 - Leste, 3 - Central, 4 - Zona da Mata, 5 - Sul e Sudeste, 6 - Alto Paranaíba, 7 - Triângulo Mineiro. MG - Minas Gerais.

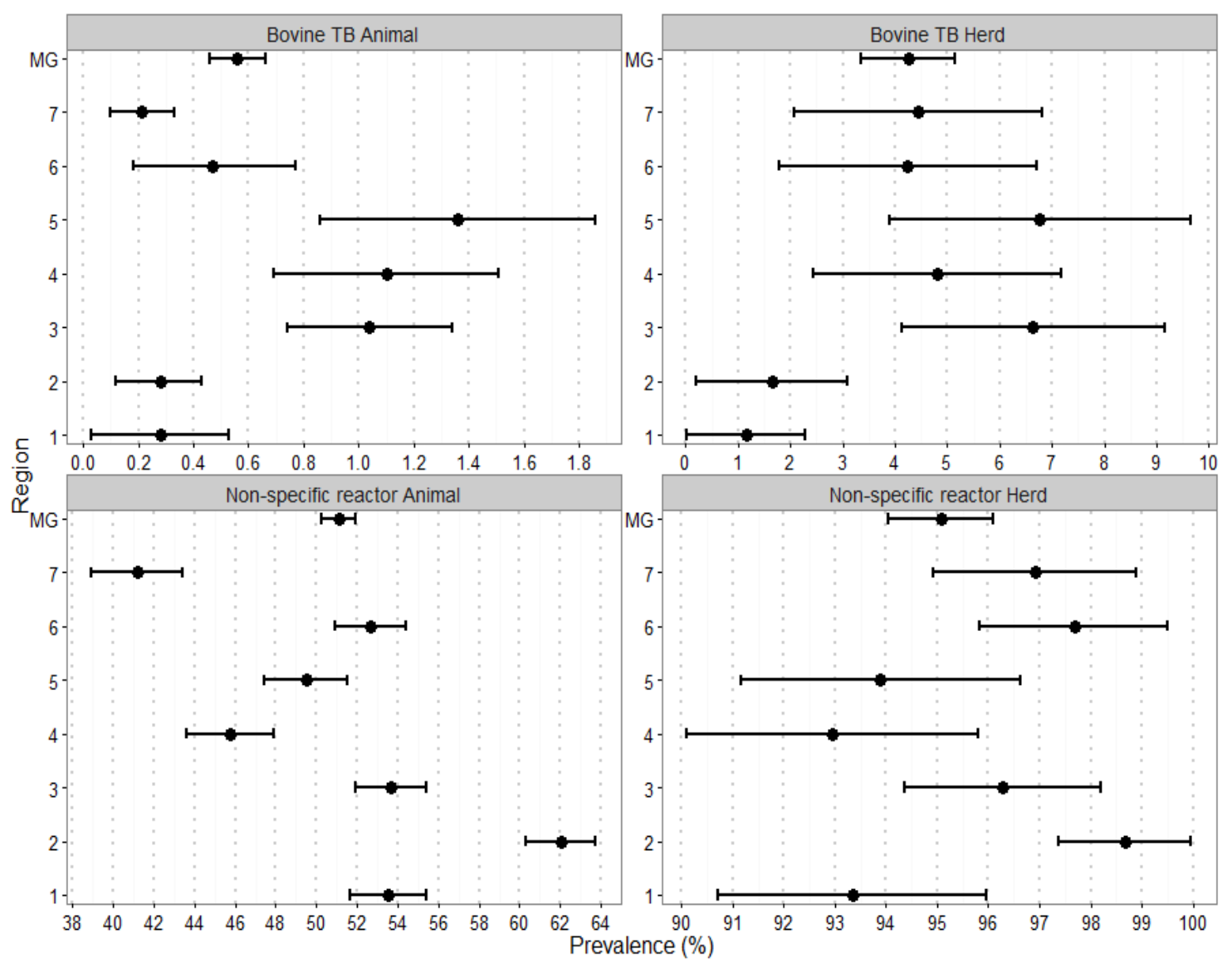


Table 4. Variables with $\mathrm{P} \leq 0.20$ analyzed with respect to their association with the occurrence of bovine tuberculosis in cattle herds of Minas Gerais, 2013.

\begin{tabular}{|c|c|c|c|}
\hline Variable & $\begin{array}{l}\text { Exposed / } \\
\text { TB Herd }\end{array}$ & $\begin{array}{l}\text { Exposed / } \\
\text { Non-TB Herd }\end{array}$ & P value \\
\hline $\begin{array}{l}\text { Type of herd regarding intensity of production } \\
\text { Beef }\end{array}$ & $6 / 93$ & $373 / 2089$ & $<0.001$ \\
\hline Non-intensive production dairy & $73 / 93$ & $1583 / 2089$ & \\
\hline Intensive production dairy & $14 / 93$ & $133 / 2089$ & \\
\hline $\begin{array}{l}\text { Production system } \\
\text { Extensive }\end{array}$ & $46 / 91$ & $1445 / 2071$ & $<0.001$ \\
\hline Semi-confined & $45 / 91$ & $614 / 2071$ & \\
\hline Confined & $0 / 91$ & $12 / 2071$ & \\
\hline $\begin{array}{l}\text { Breed } \\
\text { Zebu }\end{array}$ & $4 / 93$ & $247 / 2045$ & 0.007 \\
\hline European Dairy & $21 / 93$ & $172 / 2045$ & \\
\hline European Beef & $1 / 93$ & $10 / 2045$ & \\
\hline Crossbred & $53 / 93$ & $1433 / 2045$ & \\
\hline Other breeds & $14 / 93$ & $183 / 2045$ & \\
\hline $\begin{array}{l}\text { Presence of equines } \\
\text { Yes }\end{array}$ & $82 / 93$ & $1710 / 2089$ & 0.120 \\
\hline No & $11 / 93$ & $379 / 2089$ & \\
\hline $\begin{array}{l}\text { Presence of birds } \\
\text { Yes }\end{array}$ & $32 / 93$ & $581 / 2089$ & 0.166 \\
\hline No & $61 / 93$ & $1508 / 2089$ & \\
\hline $\begin{array}{l}\text { Presence of dogs } \\
\text { Yes }\end{array}$ & $81 / 93$ & $1696 / 2089$ & 0.152 \\
\hline No & $12 / 93$ & $393 / 2089$ & \\
\hline $\begin{array}{l}\text { Presence of cats } \\
\text { Yes }\end{array}$ & $56 / 93$ & $1108 / 2089$ & 0.175 \\
\hline No & $37 / 93$ & $981 / 2089$ & \\
\hline $\begin{array}{l}\text { Presence of marsupials } \\
\text { Yes }\end{array}$ & $34 / 93$ & $935 / 2089$ & 0.119 \\
\hline No & $59 / 93$ & $1154 / 2089$ & \\
\hline $\begin{array}{l}\text { Share the pasture with forest } \\
\text { Yes }\end{array}$ & $65 / 93$ & $1296 / 2082$ & 0.136 \\
\hline No & $28 / 93$ & $786 / 2082$ & \\
\hline $\begin{array}{l}\text { Performs test for bovine tuberculosis } \\
\text { Yes }\end{array}$ & $24 / 93$ & $232 / 2076$ & $<0.001$ \\
\hline No & $69 / 93$ & $1844 / 2076$ & \\
\hline $\begin{array}{l}\text { Acquired animals in the last two years } \\
\text { Yes }\end{array}$ & $61 / 93$ & $895 / 2077$ & $<0.001$ \\
\hline No & $32 / 93$ & $1182 / 2077$ & \\
\hline Acquired animal at auction/fair & & & 0.101 \\
\hline Yes & $14 / 61$ & $135 / 835$ & 0.101 \\
\hline No & $47 / 61$ & $760 / 835$ & \\
\hline $\begin{array}{l}\text { Acquired animal from cattle trader } \\
\text { Yes }\end{array}$ & $12 / 61$ & $98 / 895$ & 0.039 \\
\hline No & $49 / 61$ & $797 / 895$ & \\
\hline
\end{tabular}


continuation

Animal slaughter without inspection Yes

$8 / 49$

No

Animal slaughter under inspection service Yes

No

Share employee with another farm Yes

No

Existence of flooded areas Yes

No

Sell milk in bulk

Yes

No

Access to veterinary care

Yes

No

Number of cows in the herd $\leq 29$

$>29$
$41 / 49$

$36 / 49$

$13 / 49$

$3 / 12$

$9 / 12$

$38 / 91$

$53 / 91$

$58 / 89$

$31 / 89$

$53 / 93$

$40 / 93$

26/93

$67 / 93$
$365 / 1154$

$789 / 1154$

$637 / 1154$

$517 / 1154$

$153 / 330$

$177 / 330$

$710 / 2059$

$1349 / 2059$

$806 / 1940$

$1134 / 1940$

$673 / 2075$

$1402 / 2075$

1092/2089

$997 / 2089$
0.023

0.012

0.144

0.154

$<0.001$

$<0.001$

$<0.001$

TB - Herd: herds with bovine tuberculosis - positive animals; Non-TB herds: herds with no bovine tuberculosis-positive animals.

Table 5. Multivariate logistic regression analysis for the association of risk factors with bovine tuberculosis in herds of the state of Minas Gerais, 2013.

\begin{tabular}{lccc}
\hline \multicolumn{1}{c}{ Variable } & Odds Ratio & CI (95\%) & P \\
\hline Herd with 30 or more cows & 1.97 & $1.02-3.80$ & 0.042 \\
Cattle purchased from animal traders & 2.57 & $1.27-5.16$ & 0.008 \\
Type of herd regarding intensity of production & & & \\
Beef & baseline & & \\
Non-intensive production dairy & 3.50 & $1.04-11.77$ & 0.042 \\
Intensive production dairy & 7.55 & $1.89-30.16$ & 0.004 \\
\hline
\end{tabular}


Figure 4. Differences between $\mathrm{K}$ functions for herds that were positive or negative for bovine tuberculosis in the state of Minas Gerais, 2013 (dashed lines represent the upper and lower limits of the envelope; solid line represents the spatial pattern observed in 1000 simulations).

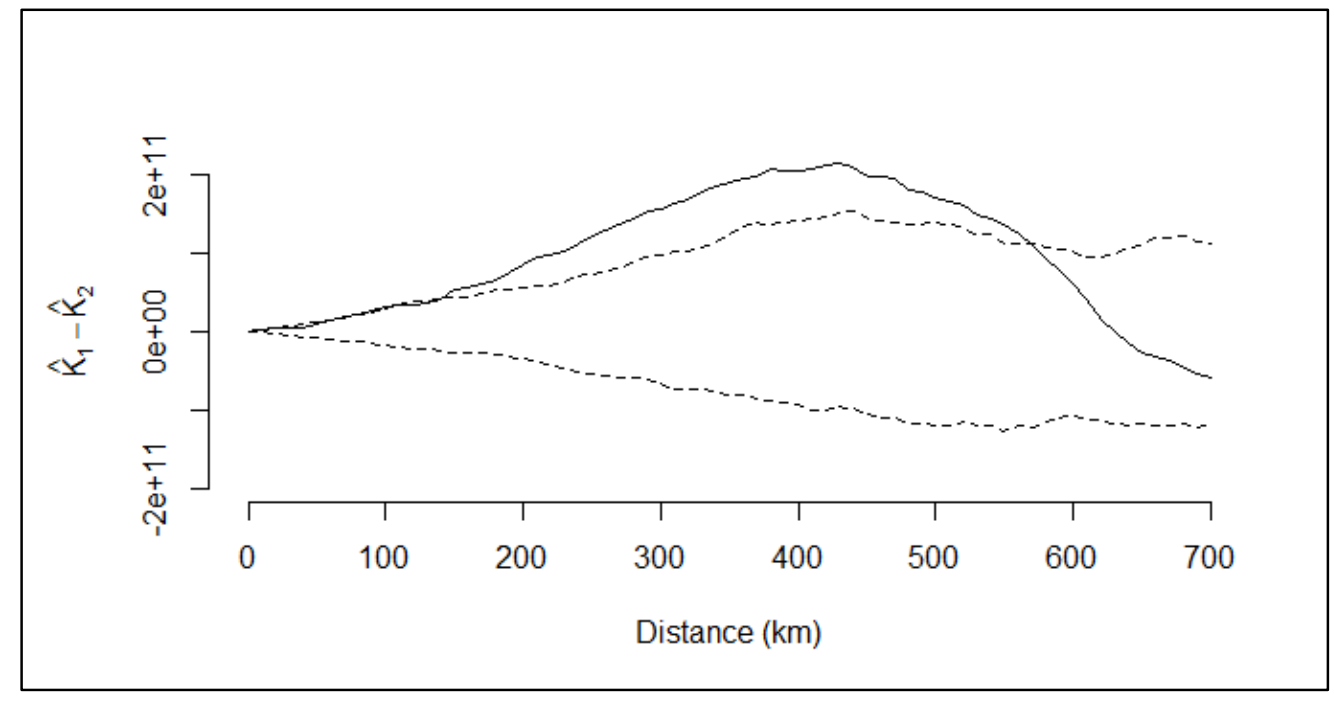

\section{Discussion}

The present study showed that bovine tuberculosis is still present in all regions of Minas Gerais at moderate herd (4.25\%) and low animal $(0.56 \%)$ levels (Tables 2 and 3, Figure 3). Knowing the epidemiological situation of bovine tuberculosis in the State more than 10 years after the publication of PNCEBT and some 15 years after the first survey of the disease on the State (BELCHIOR et al., 2016) is very important for the evaluation of the program and for identifying critical points that could be improved. Comparing to the results of the previous study in 1999 (BELCHIOR et al., 2016), which estimated herd prevalence at 5.04\% (95\% CI: $4.96 \%-5.13 \%$ ) and animal prevalence at 0.81 (95\% CI: $0.37 \%-1.25 \%)$, there was no significant change in the situation of the bovine tuberculosis in the state of Minas Gerais. It is worth noting that the 1999 survey did not cover the entirety of the State, but targeted $54 \%$ of the territory of Minas Gerais, excluding region Noroeste, Norte e Nordeste. In addition, part of the regions Alto Paranaíba and Leste of the present study, were differently defined in both studies. However, if data from region Noroeste, Norte e Nordeste (stratum 1) is withdrawn from analysis, the herd prevalence is very similar $(5.36 \%$
[95\% CI: $4.22 \%-6.50 \%])$ to the one observed in 1999. Those results showed that the actions taken by PNCEBT on Minas Gerais, namely regulatory tests for breeding stock prior to interstate movement and to entrance into livestock fairs or exhibitions and voluntary accreditation of free herds, did not change the situation of bovine tuberculosis in the State. In fact, such measures had been in place long before the onset of PNCEBT. The novel actions of the PNCEBT, such as the accreditation of free herds, have barely been implemented in Minas Gerais, which might explain why the epidemiological situation remains stable. This contrasts with the trend observed for bovine brucellosis that had a significant drop on herd prevalence from the survey performed on 2002 (GONÇALVES et al., 2009) to the one performed in 2011 (OLIVEIRA et al., 2016), mostly due to a Brucella abortus S19 vaccination program started on 1993 (OLIVEIRA, 2016).

The estimated herd prevalence of bovine tuberculosis at Minas Gerais was similar to those observed in the states of Goiás, Rondônia, Rio Grande do Sul, and Pernambuco, greater than those observed in the states of Bahia, Paraná, Santa Catarina, Mato Grosso do Sul, Mato Grosso, and Distrito Federal, and lower than those reported in 
São Paulo and Espírito Santo (BAHIENSE et al., 2016; BELCHIOR et al., 2016; DIAS et al., 2016; GALVIS et al., 2016; GUEDES et al., 2016; LIMA et al., 2016; NÉSPOLI et al., 2016; QUEIROZ et al., 2016; RIBEIRO et al., 2016; ROCHA et al., 2016; SILVA et al., 2016; VELOSO et al., 2016; VENDRAME et al., 2016). However, the comparison of the observed prevalence aggregated at state level could result in a too rough picture of the situation which precludes more refined and useful analyses.

The prevalences of bovine tuberculosis at herd level were mostly similar among the different strata in Minas Gerais (Table 2 and Figure 3). The most striking differences among regions were observed in region Noroeste, Norte e Nordeste (stratum 1) that showed the lowest herd prevalence, which was significantly different from regions Central (stratum 3), Zona da Mata (stratum 4) and Sul e Sudoeste (stratum 5) (Table 2 and Figure 3). Region Noroeste, Norte e Nordeste (stratum 1) is different from the other strata in Minas Gerais due to being predominantly a beef cattle raising region, with most of the herds using extensive production systems (ALVES, 2009; OLIVEIRA, 2016). The low herd prevalence found in stratum 1 of the present survey, region Noroeste, Norte e Nordeste, was similar to the herd prevalence observed in region Leste, stratum 2, and in bordering regions of Norte de Goiás (stratum 1) of the state of Goiás (ROCHA et al., 2016) and Sul (stratum 1) and Noroeste (stratum 2) of the state of Bahia (BAHIENSE et al., 2016). Region Norte de Goiás (stratum 1) is also a major beef cattle producing region in the state of Goiás (ROCHA et al., 2016) and regions Sul (stratum 1) and Noroeste (stratum 2), although showing the highest bovine tuberculosis herd prevalence in the state of Bahia and having important dairy herds, are also characterized by a large beef cattle raising area (BAHIENSE et al., 2016). Therefore, this large area from the North of Goiás to the East of Minas Gerais and the South of Bahia, mainly the regions Norte de Goiás, stratum 1 (ROCHA et al.,
2016) and Noroeste, Norte e Nordeste, stratum 1 of the present survey, which have a high frequency of beef herds, showed comparable low prevalence of bovine tuberculosis. Animal production practices influence the occurrence of bovine tuberculosis, which is related to animal crowding in high intensive production systems, due to the high aerial transmissibility of the disease (BRASIL, 2006; REILLY; COURTENAY, 2007). This was also observed in Minas Gerais, where regions Sul e Sudoeste (stratum 5), Central (stratum 3), Zona da Mata (stratum 4), Triângulo Mineiro (stratum 7) and Alto Paranaíba (stratum 6) had bovine tuberculosis herd prevalences between $4.24 \%$ and $6.77 \%$ (Table 2 and Figure 3), significantly higher than the prevalence observed for region Noroeste, Norte e Nordeste (stratum 1), and for most of the strata, also for region Leste (stratum2). All those regions with higher prevalences of bovine tuberculosis have a very high frequency of dairy herds (over $75 \%$ ), usually using intensive or semi-intensive production systems (OLIVEIRA, 2016). High bovine tuberculosis herd prevalences were also observed in region Campinas, Piracicaba, Bragança Paulista, Limeira, Mogi Mirim e São João da Boa Vista, stratum 5 of the state of São Paulo (DIAS et al., 2016), which borders the region Sul e Sudeste, stratum 5, and region Sul e Sudeste, stratum 2, of the state of Goiás (ROCHA et al., 2016), which borders regions Alto Paranaíba, stratum 6, and Triângulo Mineiro, stratum 7. All those regions are important dairy producing areas. Thus, all the dairy producing area from the South / Southeast of Goiás, through most of Minas Gerais, up to the North of the state of São Paulo have high prevalence of bovine tuberculosis.

These results highlight the public health risks as the consumption of raw milk is considered the major source of infection of bovine tuberculosis for the human population (MICHEL et al., 2010). A study performed on the Southeast region of São Paulo found 24 of 300 milk samples from cooling tanks from individual herds or cooperative herds 
positive for Mycobacterium spp (FRANCO et al., 2013).

Results of the spatial analysis showing clustering of bovine tuberculosis-positive herds over distances between 50 and $600 \mathrm{~km}$ (Figure 4) are probably due to the low prevalence of the disease in regions Noroeste, Norte e Nordeste, stratum 1, and Leste, stratum 2 (Tables 2 and 3 and Figure 2 and 3). This is also corroborated by the continuous areas of low and high bovine tuberculosis prevalences in Minas Gerais and the bordering states of Goiás, Bahia and São Paulo. This suggests that an integrate control policy for those states could be beneficial for them all in the control and eradication of bovine tuberculosis.

The study identified as risk factors for bovine tuberculosis in the state of Minas Gerais the purchase of animals from cattle traders, having 30 or more cows in the herd and being a dairy herd. The purchase of animals directly from livestock traders may be associated with the lack of supervision and evaluation of the health status of the animals before the introduction into the herd, which favors the transmission of bovine tuberculosis to new vulnerable herds (JOHNSTON et al., 2005; GRISI-FILHO et al., 2011). This is a risk factor, not only for the farm receiving these animals, but also for contiguous herds, given the potential of dissemination of the disease (GOPAL et al., 2006).

Herds with up to 29 cows represented the median of the number of cows per herd in Minas Gerais (OLIVEIRA, 2016), and our results shows that in larger herds there was a two-fold increase in the risk of having bovine tuberculosis reactors in the herd. Similar findings were also reported in the states of Bahia, Espírito Santo, Paraná, Santa Catarina and São Paulo where larger herds had a higher risk for bovine tuberculosis (BAHIENSE et al., 2016; DIAS et al., 2016; GALVIS et al., 2016; SILVA et al., 2016; VELOSO et al., 2016). It is known that the larger is the herd, the higher is animal exposure to infection and consequently the higher is the prevalence of bovine tuberculosis (SKUCE et al., 2012).
Dairy herds were at higher risk of bovine tuberculosis, especially intensive production dairy herds, which had almost eight times higher risk for bovine tuberculosis compared to beef herds (Table 5). Thus, this new variable was able to catch the variances contained in the original variables and produced a more robust estimator when used in logistic regression. Intensive production dairy herds usually have higher density and more stressful conditions, both being risks factors for bovine tuberculosis due to closer contact among animals, enhancing the probability of transmission by direct contact, and decreasing cattle's immunity, hence making animals more prone to infection (SKUCE et al., 2012; COWIE et al., 2014; BELCHIOR et al., 2016). Moreover, in dairy production, animals used to stay for longer time in the herds, compared to beef cattle, increasing the probability of contact with the infectious agent due to chronic presentation of bovine tuberculosis (ACHA; SZYFRES, 2003; PORPHYRE et al., 2008; BROOKS-POLLOCK et al., 2013).

Other important findings of the study were the very high prevalence of herds (more than 95\%) and a high prevalence (more than 50\%) of animals with non-specific reactions (Fig. 3). These findings had a direct impact on the diagnosis of bovine tuberculosis in Minas Gerais. PNCEBT recommends the use of the single cervical tuberculin test (SCTT) or the caudal fold test (CFT), only for beef cattle, as screening tests for bovine tuberculosis (BRASIL, 2006). Therefore, with such high prevalences of non-specific bovine tuberculosis reactions, the use of SCTT or CFT could postpone the right diagnosis of bovine tuberculosis in 60 to 90 days, until a new confirmatory CCTT would be performed, whilst increasing the cost of the diagnosis. Thus, in herds with non-specific reactors or in herds with unknown status, the use of the CCTT, a decision of the accredited veterinary, would be advisable to avoid delays in the implementation of appropriate sanitary measures. 


\section{Conclusions}

Bovine tuberculosis showed moderate herd and low animal prevalences in the state of Minas Gerais. A greater number of test positive herds were detected in regions where the dairy sector is important. The observed risk factors for bovine tuberculosis were the purchase of animals from traders, having 30 or more cows in the herd and being a dairy herd, especially intensive production dairy herd. The prevalence of non-specific reactor animals and herds were very high in Minas Gerais. The state of Minas Gerais should consider the implementation of surveillance systems for the detection and sanitation of bovine tuberculosis preferably incorporating risk-based surveillance elements, targeted at the main dairy basins.

\section{Acknowledgements}

The authors acknowledged the Instituto Mineiro de Agropecuária (IMA) for the application of the surveys, for performing the diagnostic tests in the herds, and for processing the information at the LSA/IMA. The authors also ackowledged the Animal Health Collaborating Center of the MAPA: LBA/EV/UFMG, EpiPlan/UnB; LEB/FMVZ/ USP, for the sample design and for their support in the statistical and epidemiological analysis of the data. This study was financially supported by the following organizations: Coordenação de Aperfeiçoamento de Pessoal de Ensino Superior (CAPES), Conselho Nacional de Desenvolvimento Científico e Tecnológico (CNPq), Fundação de Amparo à Pesquisa do Estado de Minas Gerais (Fapemig), Fundação de Apoio ao Ensino, Pesquisa e Extensão (FEPE), and Fundação de Apoio à Pesquisa do Estado de São Paulo (FAPESP). APL was indebeted to $\mathrm{CNPq}$ for the fellowship and to Programa Pesquisador Mineiro (PPM 00923-15) Fapemig.

\section{References}

ACHA, P. N.; SZYFRES, B. Zoonosis y enfermedades transmisibles comunes al hombre y a los animales. volumen 1: bacteriosis y micosis. $3^{\text {th }}$ ed. Washington: Organización Panamericana de La Salud, 2003. 398 p. (Publicación Científica, 580).

ALVES, C. M. Caracterização do perfil produtivo da pecuária bovina do estado de Minas Gerais, 2002. Dissertação (Mestrado em Ciência Animal) - Escola de Veterinária, Universidade Federal de Minas Gerais, UFMG, Belo Horizonte, 2009.

ANUARIO DA PECUARIA BRASILEIRA ANUALPEC. Anuário da Pecuária Brasileira. São Paulo: FNP, 2014. 303 p.

BAHIENSE, L.; ÁVILA, L. N. de; BAVIA, M. E.; AMAKU, M.; DIAS, R. A.; GRISI-FILHO, J. H. H.; FERREIRA, F.; TELLES, E. O.; GONÇALVES, V. S. P.; HEINEMANN, M. B.; FERREIRA NETO, J. S. Prevalence and risk factors for bovine tuberculosis in the State of Bahia, Brazil. Semina: Ciências Agrárias, Londrina, v. 37, n. 5, p. 3549-3560, 2016. Suplemento 2.

BELCHIOR, A. P. C.; LOPES, L. B.; GONÇALVES, V. S. P.; LEITE, R. C. Prevalence and risk factors for bovine tuberculosis in Minas Gerais State, Brazil. Tropical Animal Health and Production, Edinburgh, v. 48, n. 2, p. 373-378, 2016.

BENNETT, S.; WOODYS, T.; LIYANAGE, W. M.; SMITH, D. L. A simplified general method for clustersample surveys of health in developing countries. World Health Statistic Quarterly. Rapport Trimestrial de Statistiques Sanitaires Mondiales, Geneve, v. 44, n. 39, p. 8-106, 1991.

BIVAND, R.; KEITT, T.; ROWLINGSON, B. Rgdal: bindings for the geospatial data abstraction library. $\mathrm{R}$ package version 0. 9-2. [S.1.: s.n.], 2015. Available at: $<$ http://CRAN.R-project.org/package $=$ rgdal $>$. Accessed at: 27 may 2016.

BIVAND, R.; LEWIN-KOH, N. Maptools: tools for reading and handling spatial objects. $\mathrm{R}$ package version 0. 8-36. [S.1.: s.n.], 2015. Available at: $<$ http:// CRAN.R-project.org/package=maptoolsoject.org/ package $=$ rgeos $>$. Accessed at: 27 may 2016.

BIVAND, R.; RUNDEL, C. Rgeos: interface to geometry engine - open source (GEOS). R package version 0. 3-8. [S.1.: s.n.], 2014. Available at: <http://CRAN. R-project. org/package $=$ maptools $>$. Accessed at: 27 may 2016 .

BRASIL. Manual técnico. Ministério da Agricultura, Pecuária e Abastecimento. Secretaria de Defesa Agropecuária. Programa Nacional de Controle e 
Erradicação da Brucelose e Tuberculose Animal (PNCEBT). Brasília: MAPA, 2006. 184 p.

BROOKS-POLLOCK, E.; CONLAN, A. J.; MITCHELL, A. P.; BLACKWELL, R.; MCKINLEY, T. J.; WOOD, J. L. Age-dependent patterns of bovine tuberculosis in cattle. Veterinary Research, London, v. 44, n. 97, p. 1 -9, 2013.

COWIE, C. E.; MARREOS, N.; GORTÁZAR, C.; JAROSO, R.; WHITE, P. C. L.; BALSEIRO, A. Shared risk factors for multiple livestock diseases: A case study of bovine tuberculosis and brucellosis. Research in Veterinary Science, Oxford, v. 97, n. 3, p. 491-497, 2014.

DIAS, R. A.; STANOJLOVIC, F. M. U.; BELCHIOR, A. P. C.; FERREIRA, R. S.; GONÇALVES, R. C.; AGUIAR, R. S. C. B.; SOUSA, P. R.; SANTOS, A. M. A.; AMAKU, M.; FERREIRA, F.; TELLES, E. O.; GRISI-FILHO, J. H. H.; GONÇALVES, V. S. P.; HEINEMANN, M. B.; FERREIRA NETO, J. S. Prevalence and risk factors for bovine tuberculosis in the State of São Paulo, Brazil. Semina: Ciências Agrárias, Londrina, v. 37, n. 5, p. 3673-3684, 2016. Suplemento 2.

DIGGLE, P. J.; CHETWYND, A. G. Second-order analysis of spatial clustering for inhomogeneous populations. Biometrics, Arlington, v. 47, n. 3, p. 11551163, 1991.

DOHOO, I.; MARTIN, W.; STRYHN, H. Veterinary epidemiologic research. Charlottetown: Atlantica Veterinary College, 2003. 706 p.

ERSBOLL, A. K.; ERSBOLL, B. K. Simulation of the $\mathrm{K}$-function in the analysis of spatial clustering for nonrandomly distributed locations-Exemplified by bovine virus diarrhoea virus (BVDV) infection in Denmark. Preventive Veterinary Medicine, Colorado, v. 91, n. 1, p. 64-71, 2009.

FRANCO, M. M.; PAES, A. C.; RIBEIRO, M. G.; FIGUEIREDO PANTOJA, J. C. de; SANTOS, A. C.; MIYATA, M.; LEITE, C. Q.; MOTTA, R. G.; LISTONI, F. J. Occurrence of mycobacteria in bovine milk samples from both individual and collective bulk tanks at farms and informal markets in the southeast region of Sao Paulo, Brazil. BMC Veterinary Research, London, v. 49, n. 85, p. 1-8, 2013.

GALVIS, J. O. A.; GRISI-FILHO, J. H. H; COSTA, D.; SAID, A. L. P. R.; AMAKU, M.; DIAS, R. A.; FERREIRA, F.; GONÇALVES, V. S. P.; HEINEMANN, M. B.; TELLES, E. O.; FERREIRA NETO, J. S. Epidemiologic characterization of bovine tuberculosis in the state of Espírito Santo, Brazil. Semina: Ciências Agrárias, Londrina, v. 37, n. 5, p. 3567-3578, 2016. Suplemento 2.
GONÇALVES, V. S. P.; DELPHINO, M. K. V. C.; DIAS, R. A.; FERREIRA, F.; AMAKU, M.; FERREIRA NETO, J. S.; PORTO, T. B.; ALVES, C. M.; FIGUEIREDO, V. C. F.; LOBO, J. R. Situação epidemiológica da brucelose bovina no Estado de Minas Gerais. Arquivo Brasileiro de Medicina Veterinária e Zootecnia, Belo Horizonte, v. 61, p. 35-45, 2009. Suplemento 1.

GOPAL, R.; GOODCHILD, A.; HEWINSON, G.; DE LA RUA DOMENECH, R.; CLIFTON-HADLEY, R. Introduction of bovine tuberculosis to north-east England by bought-in cattle. The Veterinary Record, London, v. 159, n. 9, p. 265-271, 2006.

GRISI-FILHO, J. H. H.; ROSALES, C. A. R.; FERREIRA, F.; AMAKU, M.; DIAS, R. A.; FERREIRA NETO, J. S. Análise epidemiológica das condenações de bovinos por tuberculose em abatedouros do Estado de São Paulo. Arquivos do Instituto Biológico, São Paulo, v. 78, n. 2, p. 175-181, 2011.

GUEDES, I. B.; BOTTENE, I. F. N.; MONTEIRO, L. A. R. C.; LEAL FILHO, J. M.; HEINEMANN, M. B.; AMAKU, M.; GRISI-FILHO, J. H. H.; DIAS, R. A.; FERREIRA, F.; TELLES, E. O.; GONÇALVES, V. S. P.; FERREIRA NETO, J. S. Prevalence and risk factors for bovine tuberculosis in the State of Mato Grosso do Sul, Brazil. Semina: Ciências Agrárias, Londrina, v. 37, n. 5, p. 3579-3588, 2016. Suplemento 2.

HOSMER JUNIOR, D. W.; LEMESHOW, S. Applied logistic regression. $2^{\text {th }}$ ed. New York: John Wiley \& Sons, 2000. $375 \mathrm{p}$.

INSTITUTO BRASILEIRO DE GEOGRAFIA E ESTATISTICA - IBGE. Censo agropecuário de 2006, Brasil, Grandes Regiões e Unidades da Federação. Brasília: IBGE, 2006. Disponível em: <http://biblioteca. ibge.gov.br/visualizacao/livros/liv61914.pdf $>$. Acessado em: 27 maio 2016.

Produção da pecuária municipal. Brasília: IBGE, 2013. Disponível em: <ftp://ftp.ibge.gov.br/Producao Pecuaria/Producao_da_Pecuaria___Municipal/2013/ ppm2013.pdf>. Acesso em: 16 jul. 2016.

INSTITUTO MINEIRO DE AGROPECUARIA - IMA. Relatório VA-1 Maio de 2013. Belo Horizonte: [s.n.], 2013. (Relatório não publicado).

JOHNSTON, W. T.; GETTINBY, G.; COX, D. R.; DONNELLY, C. A.; BOURNE, J.; CLIFTON-HADLEY, R.; LE FEVRE, A. M.; MCINERNEY, J. P.; MITCHELL, A.; MORRISON, W. I.; WOODROFFE, R. Herd-level risk factors associated with tuberculosis outbreaks among cattle herds in England before the 2001 foot and- mouth disease epidemic. Biology Letters, London, v. 15, n. 1, p. 833-840, 2005. 
JORDAN, D.; McEWEN, S. A. Herd-level test performance based on uncertain estimates of individual test performance, individual true prevalence and herd true prevalence. Preventive Veterinary Medicine, Colorado, v. 36, n. 3, p. 187-209, 1998.

LIMA, P. B.; NASCIMENTO, D. L.; ALMEIDA, E. C.; PONTUAL, K. A. Q.; AMAKU, M.; DIAS, R. A.; FERREIRA, F.; GONÇALVES, V. S. P.; TELLES, E. O.; GRISI-FILHO, J. H. H.; HEINEMANN, M. B.; SILVA, J. C. R.; FERREIRA NETO, J. S. Epidemiological characterization of bovine tuberculosis in the State of Pernambuco, Brazil. Semina: Ciências Agrárias, Londrina, v. 37, n. 5, p. 3601-3610, 2016. Suplemento 2.

MICHEL, A. L.; MÜLLER, B.; VAN HELDEN, P. D. Mycobacterium bovis at the animal-human interface: a problem, or not? Veterinary Microbiology, Barcelona, v. 140, n. 3-4, p. 371-381, 2010.

NÉSPOLI, J. M. B.; NEGREIROS, R. L.; AMAKU, M.; DIAS, R. A.; FERREIRA, F.; TELLES, E. O.; HEINEMANN, M. B.; GRISI-FILHO, J. H. H.; GONÇALVES, V. S. P.; FERREIRA NETO, J. S. Epidemiological situation of bovine tuberculosis in the state of Mato Grosso, Brazil. Semina: Ciências Agrárias, Londrina, v. 37, n. 5, p. 3589-3600, 2016. Suplemento 2.

NOORDHUIZEN, J. P. T. M.; FRANKENA, K.; VAN DER HOOFD, C. M.; GRAAT, E. A. M. Application of quantitative methods in veterinary epidemiology. Wageningen: Wageningen Press, 1997. 445 p.

O'REILLY, L. M.; DABORN, C. J. The epidemiology of mycobacterium bovis infections in animals and man: a review. Tubercle and Lung Disease, Edinburgh, v. 76, p. 1-46, 1995. Supplement 1.

OFFICE INTERNATIONAL DES ÉPIZOOTIES OIE. Disease information. Paris: OIE, 2015. Available at: $\quad<$ http://www.oie.int/wahis_2/public/wahid.php/ Countryinformation/animalsituation $>$. Accessed at: 27 may 2016.

OLIVEIRA, L. F. Situação epidemiológica da brucelose bovina e caracterização da pecuária bovina no Estado de Minas Gerais, 2012. Tese (Doutorado em Ciência Animal) - Escola de Veterinária, Universidade Federal de Minas Gerais, UFMG, Belo Horizonte, 2016.

OLIVEIRA, L. F.; DORNELES, E. M. S.; MOTA, A. L. A. A.; GONÇALVES, V. S. P.; FERREIRA NETO, J. S.; FERREIRA, F.; DIAS, R. A.; TELLES, E. O.; GRISIFILHO, J. H. H.; HEINEMANN, M. B.; AMAKU, M.; LAGE, A. P. Seroprevalence and risk factors for bovine brucellosis in Minas Gerais State, Brazil, 2011. Semina: Ciências Agrárias, Londrina, v. 37, n. 5, p. 3437-3454, 2016. Suplemento 2.
POLLOCK, J. M.; RODGERS, J. D.; WELSH, M. D.; McNAIR, J. Pathogenesis of bovine tuberculosis: the role of experimental models of infection. Veterinary Microbiology, Barcelona, v. 112, n. 2-4, p. 141-150, 2006.

PORPHYRE, T.; STEVENSON, M. A.; McKENZIE, J. Risk factors for bovine tuberculosis in New Zealand cattle farms and their relationship with possum control strategies. Preventive Veterinary Medicine, Colorado, v. 86, n. 1-2, p. 93-106, 2008.

QUEIROZ, M. R.; GROFF, A. C. M.; SILVA, N. S.; GRISI-FILHO, J. H. H.; AMAKU, M.; DIAS, R. A.; TELLES, E. O.; HEINEMANN, M. B.; FERREIRA NETO, J. S.; GONÇALVES, V. S. P. FERREIRA, F. Epidemiological situation of bovine tuberculosis in the State of Rio Grande do Sul, Brazil. Semina: Ciências Agrárias, Londrina, v. 37, n. 5, p. 3639-3646, 2016. Suplemento 2.

R CORE TEAM - R: A language and environment for statistical computing. Vienna: R Foundation for Statistical Computing, 2014. Available at: <http://www.R-project. org/>. Accessed at: 27 may 2016.

REILLY, L. A.; COURTENAY, O. Husbandry practices, badger sett density and habitat composition as risk factors for transient and persistent bovine tuberculosis on UK cattle farms. Preventive Veterinary Medicine, Colorado, v. 80, n. 2-3, p. 129-142, 2007.

RIBEIRO, L. A.; GONÇALVES, V. S. P.; FRANCISCO, P. F. C.; MOTA, A. L. A. A.; NASCIMENTO, G. T.; LICURGO, J. B.; FERREIRA, F.; GRISI-FILHO, J. H. H.; FERREIRA NETO, J. S.; AMAKU, M.; DIAS, R. A.; TELLES, E. O.; HEINEMANN, M. B.; BORGES, J. R. J. Epidemiological situation of bovine tuberculosis in the Federal District, Brazil. Semina: Ciências Agrárias, Londrina, v. 37, n. 5, p. 3549-3560, 2016. Suplemento 2.

ROCHA, W. V.; JAYME, V. S.; GONÇALVES, V. S. P.; BRITO, W. M. E. D.; PIRES, G. R. C; MOTA, A. L. A. A.; GRISI-FILHO, J. H. H; DIAS, R. A.; AMAKU, M.; TELLES, E. O.; HEINEMANN, M. B.; FERREIRA, F.; FERREIRA NETO, J. S. Epidemiological situation of bovine tuberculosis in the State of Goiás, Brazil. Semina: Ciências Agrárias, Londrina, v. 37, n. 5, p. 3625-3628, 2016. Suplemento 2.

ROWLINGSON, B.; DIGGLE, P. Splancs: spatial and space-time point pattern analysis. R package version 2 . 01-37. [S.1.: s.n.], 2015. Available at: <http://CRAN.Rproject.org/package $=$ splancs $>$. Accessed at: 27 may 2016 .

SERGEANT, E. S. G. Epitools epidemiological calculators. Australian Veterinary Animal Health Services 
and Australian Biosecurity Cooperative Research Centre for Emerging Infectious Disease. Camberra: AUSVET, 2009. Available at: <http://epitools.ausvet.com.au>. Accessed at: 7 june 2016.

SILVA, M. C. P.; GONÇALVES, V. S. P.; MOTA, A. L. A. A.; KOLODA, M.; FERREIRA NETO, J. S.; GRISIFILHO, J. H. H; DIAS, R. A.; AMAKU, M.; TELLES, E. O.; FERREIRA, F.; HEINEMANN, M. B.; ALFIERI, A. A.; MULLER, E. E. Prevalence and risk factors for bovine tuberculosis in the Paraná State, Brazil. Semina: Ciências Agrárias, Londrina, v. 37, n. 5, p. 3611-3624, 2016. Suplemento 2.

SKUCE, R. A.; ALLEN, A. R.; McDOWELL, S. W. J. Herd-level risk factors for bovine tuberculosis: a literature review. Veterinary Medicine International, v. 2012, Article ID 621210, p. 1-10, 2012.

THRUSFIELD, M. Veterinary epidemiology. $2^{\text {th }}$ ed. Cambridge: Blackwell Science, 1995. 479 p.
VELOSO, F. P.; BAUMGARTEN, K. D.; MOTA, A. L. A. A.; FERREIRA, F.; FERREIRA NETO, J. S.; GRISI-FILHO, J. H. H.; DIAS, R. A.; AMAKU, M.; TELLES, E. O.; HEINEMANN, M. B.; GONÇALVES, V. S. P. Prevalence and herd-level risk factors of bovine tuberculosis in the State of Santa Catarina, Brazil. Semina: Ciências Agrárias, Londrina, v. 37, n. 5, p. 3659-3672, 2016. Suplemento 2.

VENDRAME, F. B.; AMAKU, M.; FERREIRA, F.; TELLES, E. O.; GRISI-FILHO, J. H. H.; GONÇALVES, V. S. P.; HEINEMANN, M. B.; FERREIRA NETO, J. S.; DIAS, R. A. Epidemiologic characterization of bovine tuberculosis in the State of Rondônia, Brazil. Semina: Ciências Agrárias, Londrina, v. 37, n. 5, p. 3639-3646, 2016. Suplemento 2.

ZAR, J. H. Biostatistical analysis. $5^{\text {th }}$ ed. New Jersey: Prentice Hall, 2010. 944 p. 